\title{
The Use of Primaries by Political Parties: The Case of PASOK - A Comment
}

\author{
By Domenico Fruncillo*
}

\begin{abstract}
This paper comments on Professor Papanikos' recent publication in this journal entitled, "The Use of Primaries by Political Parties: The Case of PASOK". I make a number of observations regarding the argument of the author that primary elections are an application of democracy in the internal procedures of a political party. The question raised is whether primaries enhance democracy, or restrict it, by diminishing the role of party members only in selecting party representatives and have no role in the discussion of policies. Another important issue is the age structure of the participants in the primary elections. Did it matter? More analysis and evidence is needed on this issue to find out whether the relatively younger candidate mobilized more young members and friends to participate in the primary elections of PASOK.
\end{abstract}

Keywords: primaries, elections, voting, political parties, PASOK, Greece

In a special volume of the Athens Journal of Social Sciences (see Papanikos 2022a for an introduction to the volume), the issue of primary elections was examined by Papanikos (2022b). His paper is very interesting for its literature review, its theoretical framework and most importantly for the arguments raised.

The specific theme of his paper is the Panhellenic Socialist Party's (PASOK) primary elections since 1996 with an emphasis on the most recent ones of December 2021. This case study allows the author to cut across some extremely relevant general issues: (a) the evolution of the party form; (b) the role of ideology in political-electoral competition; and (c) the generational resource as a lever of political innovation.

To answer the general question regarding the weight of ideology in primary competition - and ultimately in party electoral performance--the author relates the different types of primaries, the role of primaries and the purpose for which they are set up, and the utilization of ideology as a distinguishing characteristic of the profile of different primary candidates. In this comment here, I shall try to make a few observations as far as the organic and coherent text is concerned.

According to the well-known proposal formulated by Kircheimer (1966) half a century ago, the catch-all party, compared to the previous models of the mass party (bureaucratic, integration), had a much less substantial ideological inclination. Progressively, the weight of ideology in the definition of the politicalelectoral proposal aimed at the formation of consensus among the general electorate has been further reduced for all parties. Even though this is true with reference to the exposure addressed to the electorate at large, the ideological dimension, nevertheless, remains relevant for the traditional parties or their heirs and descendants. PASOK could be counted as belonging to these political parties. In particular, the ideology still plays an important role with reference to the

*Professor, University of Salerno, Italy. 
definition of the competitive space between the different elites. As Panebianco (2012) argues, it prevents the ruling groups from distancing themselves in a striking way from the cultural tradition of the old parties; it delimits the boundaries to the definition of the internal competitive field.

One of the "ideological" issues of the surviving traditional parties concerns the ideal of democracy, which is more demanding: democracy is not only defined as free competition between parties, but it exits as a competition within the party. In a way it is considered that democracy is better served if it is practiced inside the parties. This idea runs through the entire argument of Papanikos (2022b) paper and is explicitly stated in the conclusion. It deserves some reflection.

According to a rather recurrent and widespread approach, internal democracy in parties is achieved through the opening of procedures for the selection of candidates in general elections and for the identification of the central leadership (Hazan 2002, Katz 2001, Le Duc 2001). Recruitment of political personnel is one of the functions that still seems to be at the disposal of political parties; the possibility that this function be taken away from internal "oligarchies" and put into the hands of partisan party members and sympathizers certainly represents an advancement of democracy not only within parties, but in general. Not surprisingly, the self-referentiality of party elites has been considered a feature of post-democracy (Crouch 2003, 2020) and has been related to the retreat of citizens' ability to influence political choices through elections (Fruncillo 2020).

However, this dynamic political process could also trigger obstructive and unintended effects. Firstly, one of these is recalled in the essay and concerns the role of loyal members who could be disincentivized to militant commitment since it is essentially "equalized" to occasional outside sympathizers. Obviously, this risk is not there if the primaries are closed. However, it should not be underestimated in the case of open, or even blanket, primary elections. PASOK's primary elections were open to all members and friends, but not to other party members.

Secondly, direct election legitimizes the candidate as representing a much wider number of the electorate, which is much less than what the party itself represents. Consequently, once elected, the candidate may feel little responsibility towards loyal party members and more committed to responding to the demands of the general electorate. This is an outcome that some consider desirable, but which entails a further disincentive to political commitment in the parties, which risk becoming more and more only labels available to individuals who see politics as a career and not so much as a place where effective discussions about policies occur.

Finally, the candidate, legitimized by direct investiture, cultivates the relationship with his or her own selectors and feels free from committing to the necessary discussions within the party. In this way, democracy within the party is strengthened at the moment of candidate selection, but risks becoming impoverished and limited only to the selection of political representatives.

It would be useful if the essay, with respect to these possible scenarios, evolutions, and effects described what has happened to PASOK in this now long period of experimentation with primaries. Obviously, it is well understood to me 
that this is not the main topic of the paper, but some information on these aspects could offer elements that could illuminate the central question, and that concerns the appeal of ideology with reference to the different types of participants in the primaries.

In Italy, the enthusiasm for primaries is present in the experience of the democratic party well known to the author of the essay. The primaries have shown their capacity for party innovation, but they have also proven to be a constraint and a burden on its political and organizational development as I have argued in Fruncillo (2017) published in a special issue of this journal (Maddaloni 2017).

A few particular observations relate to the appropriateness of constructing a single paragraph on previous primaries. With regard to the analysis of the primaries of 2021, it would be useful to make some reference to the capacity of the primaries to allow for occasional or medium-term provisional organizational development and the capacity of the less ideologically connoted leadership as a lever of mobilization to vote in the primaries and as a resource to increase the consensus of the electorate more generally.

With regard to the first question, it would be useful to observe the number of party members even in the years in which the primaries were not held. It would be useful to have some indicator of the mobilization capacity of the candidates who are more ideologically connoted; at least as far as their position on the traditional right-left axis is concerned. In this regard, although very suggestive, the experiment developed with reference to the weak ability to mobilize potential supporters to vote as a reason for his defeat does not appear entirely convincing.

In reference to the second aspect, it could be interesting to expose the relationship between the participants in the primaries and the consensus obtained by PASOK. Obviously, for the 2021 primaries it is not yet possible to have this feedback. Some suggestion comes from the Italian case. In 2019, after the exhaustion of the Renzi experience, the primaries that led to the election of Nicola Zingaretti seemed more ideologically connoted if one considers the orientation of Zingaretti's selectors regarding the issue of migration (Fruncillo 2019).

A final consideration concerns the age aspect. My question is: could the success of the younger candidates be the result of the greater presence among the electorate of young people more inclined and interested in these forms of participation? This hypothesis obviously does not exclude, and does not conflict with, the interpretation offered by the author whereby the electoral shocks have convinced the PASOK base to entrust the objective of returning to power to a candidate who represents the younger generation of PASOK's members.

\section{References}

Crouch C (2003) Postdemocrazia. (Post-democracy). Roma-Bari: Laterza

Crouch C (2020) Combattere la postdemocrazia. (Fighting post-democracy). Roma-Bari: Laterza.

Fruncillo D (2017) Populism and the Italian electorate: towards a democracy without parties? Athens Journal of Social Sciences 4(3): 285-310. 
Fruncillo D (2019) Immigrazione: un tema che riconnette base ed élites. (Immigration: a theme that reconnects base and elites). In S Rombi, F Serricchio (eds.), L'elezione di Zingaretti. La Rivincita del Partito? 155-166. Novi Ligure: Epochè.

Fruncillo D (2020) Verso la politica post-elettorale. (Towards post-election politics). Soveria Mannelli: Rubbettino.

Hazan RY (2002) Candidate selection. In L Le Duc, RG Niemi, P Norris (eds.), Comparing Democracies 2. New Challenges in the Study of Elections and Voting, 108-126. London: Sage.

Katz RS (2001) The problem of candidate selection and models of party democracy. Party Politics 7(3): 277-296.

Kirchheimer O (1966) The transformation of the Western European party systems. In J LaPalombara, M Weiner (eds.), Political Parties and Political Development, 177202. Princeton, NJ: Princeton University Press.

Le Duc L (2001) Democratizing party leadership selection. Party Politics 7(3): 323-341.

Maddaloni D (2017) Special Issue on Southern European countries facing neoliberal globalization: an introduction. Athens Journal of Social Sciences 4(3): 207-210.

Panebianco A (2012) Political parties. In International Encyclopedia of Political Science, 356-363. New York: Sage.

Papanikos GT (2022a) Democracy and politics: an introduction to the special issue of the Athens Journal of Social Sciences. Athens Journal of Social Sciences 9(2): 89-94.

Papanikos GT (2022b) The use of primaries by political parties: the case of PASOK. Athens Journal of Social Sciences 9(2): 201-222. 